\title{
Exports, Exchange Rates and Productivity: An Analysis of the Japanese Manufacturing Sectors*
}

\author{
Atsuyuki Kato \\ Kanazawa University and RIETI 1
}

Abstract

This paper examines the effects of exchange rate changes and productivity on manufacturing exports. Using the dataset of the Japanese manufacturing firms during the period, $2002-2012$, we discuss if exchange rate fluctuations deter export activities and if productivity and markup differences affect it. For this study, we estimate both firm specific productivity and markups by the production function based approaches and incorporate them into the Heckman sample selection model. Our results show exchange rates are important factors to affect firmlevel exports as a whole while temporal aggregation should be carefully considered. In addition, this study also reveals that productivity and markup give different impacts on firm-level exports across industries. In the transportation equipment industry, negative effects of appreciation on exports are partly mitigated by higher productivity. Markups are positively related to exports in the electronics industry while negative in the transportation equipment. Neither productivity nor markup absorbs the impact of exchange rate changes in the machinery industry. Those findings imply that stability of exchange rates is very important while the effective trade policy may vary across industries following their trade structure.

\section{JEL Codes: F1, F31}

\section{Introduction}

Large fluctuation of exchange rates of the Japanese yen after the Lehman shock reignited debates on the effect of exchange rate changes on exports. Some have insisted that the sharp drop of the Japanese exports accompanied by the appreciation of the currency clearly illustrates the effect of exchange rate changes on exports. Some, on the other hand, say that the Japanese exporting firms have already established the resilient production networks against exchange rate turbulence across the Asian region. Their conflicting views led the completely opposite approaches to the exchange rate policy. The former people believed that the appreciation of yen after the Lehman shock exceeded the acceptable level and the government should have controlled such rapid appreciation, to support exporters while the latter thought that the effective exchange rates were still relatively stable compared to the disastrous appreciation in the mid-1990s and lots of exporters could absorb the impacts through their sophisticated production and supply networks. Many papers have measured the effect of exchange rate changes on exports and contributed to this issue so far. This paper is also a part of those studies. We provide additional empirical evidence for such debates.

The aggregate level data have largely been used in the papers on this issue so far. To discuss the details of export activities, many papers have examined the relations between export and exchange rate changes at the product level. For example, Thorbecke and Kato (2012) estimated the elasticity of Japanese consumption exports on exchange rate fluctuations, and illustrated that both bilateral and competitors' exchange rates are statistically significant. Kato (2015a) also applied the similar approach to technology-intensive exports by East Asian economies, and detected that both high and medium skill and technology intensive exports are responsive to exchange rate changes in Japan². Rahman (2009) also estimated the impact of exchange rate fluctuation on exports for East Asian countries by a different approach and found that intra-regional flexibility had larger impacts on Japan's exports than bilateral ones. In addition, many papers examined those impacts within discussion of exchange rate pass-through such as Shioji (2012).

Compared to the literature using the aggregate data, studies using the firm-level data on this issue have been less accumulated. This is partly because trade data is less available at the firm level. In particular, export volumes by different

\footnotetext{
* This work was supported by JSPS KAKENHI Grant Number 25380338, and a part of research result undertaken at RIETI.

1 Exchange rates were not statistically significant in the model that allowed heterogeneous time trends.

2 Exchange rates were not statistically significant in the model that allowed heterogeneous time trends.
} 
export markets at the firm level are poorly obtainable even though many exporting firms have several export destinations ${ }^{1}$. It makes us difficult to construct data of firm-specific exchange rates as well. To control this problem, Guillou (2008) assumed that all firms export their products to the imaginary unique market and constructed industry-specific exchange rates (the weighted exchange rates by export shares). For French firms, she concluded that exchange rates have statistically significant influence on export entry but don't do on export intensity.

Morikawa (2015) examined the relations between uncertainty over exchange rates and exports and detected statistically significantly negative impacts using Japanese data. Ando and Kimura (2013) also revealed that Japanese manufacturing firms are responsive to exchange rate changes, and the responsiveness is higher in the multinational enterprises (MNEs) with intra-firm transactions.

In addition to exchange rates, productivity is considered as an important factor for the firm-level export in theoretical studies such as Melitz (2003), Helpman, Metlitz, and Yeaple (2004), and Melitz and Ottaviano (2008). Berman, Martin and Mayer (2012) incorporated those implications into the relations between exchange rates and exports using rich French data and found that more productive firms use their markup to absorb the impacts of exchange rate changes instead of their export volume. Li, Ma, Xu and Xiong (2015) examined those relations for Chinese firms and also indicated that firms with higher productivity change the prices to absorb exchange rate fluctuation while firms with lower productivity do their export volume.

This paper would also like to examine the relations between exchange rates and exports at the firm level. Unlike the cases of French and Chinese firms, neither unit value nor quantity of exports is available for the Japanese firms. Export values are, however available by region. Thus, we incorporate regional differences into Guillou's approach in this paper. In addition, we examine if productivity and markup affect export activities, reflecting the findings by Kato $(2015 b)^{2}$.

The layout of this paper is as follows. In the next section, we explain the empirical framework of this study. Section 3 details the data. In section 4, we present empirical results. And the last section is a concluding remark.

\section{Empirical Framework}

In this section, we briefly explain the methodology to estimate the firm-specific productivity and markup, and describe the model of our regression analysis. At first, we estimate the firm specific productivity and markup, and then examine if the firm level export is sensitive to the exchange rate fluctuation and if productivity and markups affect such sensitivity. The productivity and markup are estimated by a production function based approach developed by Martin (2010)3. An advantage of this approach is to allow us to estimate the relative productivity and markup to the reference firm without price information that is usually unavailable at the firm level (details in Martin (2010) and Kato (2010)).

In this approach, we assume that each firm has the following production function,

$$
Q_{i}=A_{i}\left[f\left(\mathrm{X}_{i}\right)\right]^{x}
$$

where $Q_{i}, A_{i}, \mathrm{X}_{\mathrm{i}}$ are quantity of output, Hicks-Neutral technology, and a vector of inputs, respectively. $\gamma$ is the degree of returns to scale and $\gamma>0$. The subscript $i$ means firm $i$, and $i=1, \ldots n^{4}$. On the other hand, a demand function that each firm faces is represented as follows,

$$
Q_{i}=D\left(P_{i}\right)
$$

\footnotetext{
1 Trade data at the product or the production process level are poorly available as well.

${ }^{2}$ Kato (2015b) revealed that the Japanese exporting manufacturers possibly give different roles to different export markets. If so, their reaction to exchange rate changes may vary across their markets as well.

3 This approach is also employed in Kato (2010), Kato and Kodama (2014), and Kato (2015b).

${ }^{4}$ Our estimation implicitly assumes that the price of each input is identical across firms. Although this assumption is very restrictive and ad hoc, Eslava et al. (2005) reveals that ignoring input prices give little effects on productivity estimation using Columbian data.
} 
From equations (1) and (2), we obtain a revenue function for each firm is as follows,

$$
r_{i}-\sum_{X \neq K} \bar{s}_{X i}\left(x_{i}-k_{i}\right)=\tilde{r}_{i}=\gamma \frac{\overline{1}}{\mu_{i}} k_{i}+\frac{\overline{1}}{\mu_{i}}\left(\lambda_{i}+a_{i}\right)+\tilde{\varepsilon}_{i}
$$

where lower case variables denote logs of deviation from the reference firm for each variable. $r, s$, and $\mu$ are the total revenue, the revenue share of variable, and the firm-specific markup, respectively. Here, $X$ is a temporary adjustable input such as labour and intermediates. $\mathrm{k}$ is capital and assumed to be fixed for the short run as well as many existing papers on productivity analysis. $\lambda$ and a are respectively consumers' valuation of firm is product and technical efficiency. Using them, firm-specific quality adjusted productivity is represent as $\omega_{i}=\left(\lambda_{i}+a_{i}\right)$.

In estimation of equation (3), $\omega$ is possibly correlated with capital ${ }^{1}$. To solve this endogeneity problem, we apply a control function approach following Olley and Pakes (1996), Levinsohn and Petrin (2003), Bond and Söderbom (2005), and Ackerberg et al. $(2006)^{2}$, using capital and net revenue to approximate $\omega$. On the other hand, markup is represented as a function of revenue share and adjustable input factors as follows,

$$
\frac{1}{\mu_{i}}=s_{x i}\left(\frac{\partial \ln F_{i}}{\partial \ln X_{i}}\right)^{-1}=s_{x i} \Psi\left(\mathbf{X}_{i}\right)
$$

where $F$ and $\mathbf{X}$ are the production function and the vector of inputs, respectively. Since the functional form of $\Psi($.$) is$ also unknown, it is approximated in the same manner to $\omega$. In this approach, we estimate the relative productivity and markup as $\omega / \gamma$ and $\mu / \gamma$ because we have no information on the degree of $\gamma$. However, it is not thought to give a bias in discussion below because $\gamma$ is assumed constant across firms.

Using these estimates of relative productivity and markup, we examine the relations between exports and exchange rate fluctuations at the firm level as well as firm characteristics including heterogeneous productivity and markup.

The regression model is as follows,

$$
E X_{i t}=\beta_{1} \pi_{i t}+\beta_{2} \omega_{i t}+\beta_{3} \mu_{i t}+\beta_{4} E X_{i t-1}+\sum \delta_{j} X_{j i t}
$$

where $\mathrm{EX}, \pi$, and $\mathrm{Z}$ are respectively exports, exchange rates, and control variables. In this paper, firm exports, $\mathrm{EX}$ is the export share to total sales (export intensity) for each firm, instead of export values following Guillou (2008). This is because a sensitivity of export intensity to exchange rate changes illustrates a price effect in any case as she discussed. In addition, the lag of EX is also included to control export sunk costs for each firm. The control variables $X$ include firm size $(=\log$ of number of workers), import shares to total sales, labour and capital intensities.

A problem in this regression is that the dependent variable includes many zeros and OLS is not reliable. To solve this problem, some approaches have been considered in the existing literature such as Tobit, Zero-Inflated Poisson, and Heckman two step approaches ${ }^{3}$. Among them, we use the Heckman two step approaches because of the following reasons. First, Tobit and Zero-Inflated Poisson implicitly assume that the selection and the regression models have the identical set of explanatory variables, but the factors to determine export entry and export intensity may be different ${ }^{4}$. Second, the results are comparable from those in Guillou (2008) because she also applied the Heckman two step method to French firms.

\footnotetext{
${ }^{1}$ Ichimura, Konishi and Nishiyama (2011) discusses the case that labour is also correlated to productivity.

2 Wooldridge (2009) proposes another approach using GMM.

${ }^{3}$ Heckman (1979).

${ }^{4}$ Another problem in those two methods is that the dynamic model with endogeneity is not well examined. Wooldridge (2005) developed a dynamic tobit approach but largely unbalanced panel like our data is not well discussed.
} 
In the Heckman two step approach, the selection function is represented as follows,

$\mathrm{I}_{\mathrm{it}}=\zeta_{1} \omega_{i t}+\zeta_{2} \mu_{i t}+\sum \eta_{j} Z_{j i t}$

where $\mathrm{I}$ is unity if firm i exports its products, otherwise zero. $Z$ is a set of control variables. The dummy variable of foreign direct investment (FDI) is included in Z because FDI is thought to play the important role for Japanese firms to export their products through supply chains. FDI dummy takes unity if a certain firm has oversea establishments, otherwise zero. Foreign ownership is also considered as an important control variable. As well as equation (5), productivity and markup are included in the set of control variables following the implication from theoretical models.

\section{Data}

Our data for estimation of the firm productivity and exports are obtained from the Basic Survey of Japanese Business Structure and Activities (BSBSA)1. Following the existing empirical literature using this data source, total sales and the tangible fixed assets are used as proxies of total revenues of firms $(R)$ and capital $(K)$, respectively. Labour inputs are calculated as man-hour data following Morikawa $(2010)^{2}$. Total wages are considered as labour costs. From the definition of the value added in the Ministry of Economy, Trade and Industry (METI), the proxy of intermediate inputs is constructed as follows,

Intermediate Imput $=\mathrm{COGS}+\mathrm{SGA}-(T W+D e p+T \& D) \quad(7)$

where COGS, SGA, TW, Dep and T\&D are the cost of goods sold, the selling and general administrative expenses, the total wages, the depreciation and the tax and dues, respectively ${ }^{3}$. In our data, the observations whose number of regular workers, tangible fixed assets, total wages, or intermediate inputs is zero or negative are excluded. Export intensity is measured as the share of exports to total sales.

A problem in studies on the relations between exports and exchange rate changes at the firm level is how to measure the exchange rate changes for each firm. Firms usually export their products to various markets although the statistical data doesn't always include details of exports. As we mentioned above, Guillou (2008) assumed that all firms export their products to the imaginary single market. In her work, she measured the weighted exchange rates between France and French trade partners at the industry level as the exchange rates for each firm, to control industrial differences. We, however, don't apply this approach to the current paper. Japanese firms may give different roles to different markets as the existing literature discussed. Kato (2015a) implied that Asian markets are the parts of their production networks while North America (in particular, the US) is the market for their finished goods. Such differences possibly affect the relations between exchange rates and exports. We, therefore, measure the regionally weighted exchange rates for each firm to control them ${ }^{4}$. Figures 1 and 2 show that Japan's exchange rates and exports by region at the aggregate level. They illustrate that Japan's exchange rates and exports have been largely swung during the examined period and export weights vary across regions. It also justifies that we use the regionally weighted exchange rates in this analysis.

Exchange rates are obtained from the Bank of Japan (BOJ) statistics. We obtained monthly average rates and demeaned them from April to next March as Japanese fiscal year average rates because financial data in the BSBSA are compiled at the Japanese fiscal year. The exchange rate volatility is calculated as a one-year standard deviation of the first difference of the logarithm of the monthly exchange rate between Japan and her trade partner following the existing literature 5 .

We focus on export of products by the manufacturing firms because it is almost impossible to obtain data of service trade at the firm level. In this paper, we classify the manufacturing sector into 11 industries (see Appendix). Table 1 illustrates the share of each region in exports and the share of exports to total sales. It indicates that Asia accounts for the lion's share of Japanese exports in all manufacturing industries. The weights of Asia are, however, distributed from $75 \%$ (Plastics) to

\footnotetext{
1 This statistics is annually compiled by the Ministry of Economy, Trade and Industry (METI) Japan and covers the firms whose employees are more than 50 or capital is over 30 million Japanese yen.

2 The average working hours at the industry level are from Monthly Labor Survey; http://www.mhlw.go.jp/english/database/db-l/monthlylabour.html

3 Tokui, Inui and Kim (2007) and Kim, Kwon and Fukao (2008).

${ }^{4}$ BSBSA reports export values at the regional level for each firm. Within each region, we calculate the exchange rates weighted by the aggregate export data.

${ }^{5}$ Darby et al. (1999), Tenreyro (2007), and Guillou (2008). They use quarterly exchange rates and two-year standard deviations.
} 
$52 \%$ (Transport). Roughly speaking, Asia's shares are much higher in industries of intermediate products such as Plastics, Glasses and Metals while it is relatively lower in industries of finished goods such as Transports. Export shares to total sales considerably vary across industries as well. Export shares are higher in the machinery related industries while lower in the light industries. These seem to reflect the structure of Japan's exports.

Table 2 presents the distribution of firms by size and the ratio of exporters in each size category. Here, we classified firms into three size categories; over 500 workers, $100-500$ workers, and less than 100 workers ${ }^{1}$. The majority of firms fall into the middle size categry in all industries. The table reveals a consistent pattern on the ratio of exporters. In all industries, the ratio is highest in the large firm category while it is lowest in the small firm category. Thus, the size is important factor in the firm-level export. Although this pattern is consistent, the shares of exporters considerably vary across industries in all size categories. In the large size category, the lowest is 19.39 percent (Foods) while the highest is 79.50 percent (Electronics). In the middle size category, the lowest is 9.74 percent (Foods) while the highest is 56.07 percent (Machines). Such differences possibly justify the industry-by-industry estimation in the following section.

\section{Empirical Results}

This section describes empirical results and discusses those implications. First, we briefly review estimation results of productivity and markup, and then discuss the regression between exports and exchange rates. Table 3 presents the weighted means of productivity and markups for both exporters and non-exporters. Interestingly, non-exporters have higher average productivity than exporters in some industries although many existing papers revealed that exporters have relatively higher productivity than non-exporters. However, it does not always mean that our findings are contrary to those of the existing papers. In many existing papers, productivity is measured as total factor productivity (TFP) while we decompose TFP into technical efficiency and the pricing power (markup) ${ }^{2}$. We should, therefore, look at markup as well as productivity between exporters and non-exporters, to compare to the existing literature. The table reveals that there is no industry that the demeaned productivity and markup for exporters are simultaneously lower than those for non-exporters. It possibly indicates that the structure of exports vary across industries. In Textile, Chemicals, Glasses, Metals and Machines, exporters have advantages on their markup by differentiated products. On the other hand, exporters have higher productivity in the other industries. It is also consistent with our intuitive view that Japanese capital, equipment and material exports are differentiated with high quality within the regional networks while finished goods and electronics are more open to price competition because of catching up by Asian competitors.

Next, we discuss the estimation results but we should re-consider data distribution. The tables 1 and 2 reveal that export is very biased to large firms in three industries; Machines, Electronics and Transport. In other industries, exporters are also biased to the large firms but the shares of export to total sales are very small. We focus on those three industries in this analysis, concerning over the reliability of the estimation results. This also seems to be reasonable because those three industries cover Japan's major exporting products such as industrial machines, equipment, electronic products and automobiles. The results of the regression models in Heckman two step approaches are presented in Tables $4^{3}$. The left hand side of the table reports the estimation using the average exchange rate as a proxy of exchange rate changes. The results illustrate that coefficients of the lagged dependent variable in all industries are statistically significantly positive. In addition, the estimates are close to unity. It indicates that the sunk cost exists in the firm-level export and it is difficult for firms to drastically change their export intensity following exchange rate changes ${ }^{4}$. In addition, the firm size is also statistically significantly positive in those industries. Thus, the larger the firms are, the more the firms develop oversea markets ${ }^{5}$. The effects of exchange rate changes vary across industries. Electronics and Transport have statistically significantly negative coefficients as we expected. On the other hand, in Machines, the estimated coefficient for the exchange rate is negative but statistically insignificant. In the former two industries, a $1 \%$ appreciation decreases the export intensity by $4.6 \%$ and $3.4 \%$, respectively. The estimated coefficients for productivity are statistically significantly positive

\footnotetext{
${ }^{1}$ Sum of the regular and the contingent workers

2 TFP is represented using our productivity $(\omega)$ and markup $(\mu)$ as follows,

$\mathrm{TFP}=\left(\frac{\bar{\gamma}}{\mu}-1\right) \mathrm{k}+\frac{\overline{1}}{\mu} \omega+\varepsilon$.

3 The results of other industries are available upon request.

4 It is also true in other industries.

5 Unlike the lagged export intensity, it is not always true in other industries.
} 
only in Transports. It implies that exporting firms in the transportation equipment industry possibly offsets negative effects of currency appreciation by higher productivity to some extent. . It is also difficult to find a unique implication on markup. Electronics has a statistically significantly positive estimate while Transport has a statistically significantly negative estimate. It implies that products in the former industry are differentiated to some extent while products in the latter one face severe price competition in oversea markets. .

In the right hand side of in the table, exchange rate volatility is used as a proxy of exchange rate changes instead of the average exchange rate. Compared to the average exchange rate, all industries obtain statistically significantly negative estimates on exchange rate volatility. For productivity and markup, we obtain the same implications as the case of the exchange rate levels. The lagged dependent variable is still statistically significantly positive and close to unity.

The differences between the exchange rate level and volatility possibly stem from the differences in the timing of exchange rate adjustment across industries. In other words, the temporal aggregation may be inappropriate for the machinery industry. As is well known, exporting firms have fixed exchange rates during the contract period, and the lengths of the contracts are possibly different by industry. On the other hand, the volatility measure can avoid such a problem to some extent. Thus, the statistically significantly negative estimates on exchange rate volatility are considered as evidence that large exchange rate fluctuation has significantly negative impacts on the firm-level export.

Our results also reveal that neither productivity nor markup advantage can absorb the negative impacts of large fluctuation of exchange rates on exports in the machinery industry. It does not support the view that Japanese exporters can effectively control the impact of exchange rate changes through their sophisticated supply chain networks because the machinery exports can play key roles in such networks. Instead, stability of exchange rates seems to be still important in industrial policies.

Table 5 gives the results of the selection model. In Machines and Electronics, productivity is positively correlated with export while markup is negatively correlated. In Transport, markup is weakly negatively correlated with export. Those findings coincide with the implications in Bellone et al. (2008). It characterizes export activity by Japanese firms to some extent because those industries play important roles in overall Japanese exports as we mentioned above. The lagged dependent variable is statistically significantly positive even in the selection model. The FDI dummy (oversea establishment) and foreign capital ratios are statistically significant only in Electronics ${ }^{1}$. These findings support the view that differences in industrial structure possibly influence their export structure as well.

\section{Conclusion}

We examined the effect of exchange rate changes, productivity and markup on export intensity at the firm-level. Our estimation revealed that large volatility of exchange rates has significantly negative effects on export intensity of firms. On the other hand, the effect of currency appreciation should be carefully examined because the temporal aggregation may affect the results of estimation. As a whole, we conclude that the exchange rate stability is important in export promotion policies. We also detect that productivity and markup affect export of firms through varying paths across industries. It implies that differences in industrial structure should be carefully considered in devising export promotion policies. As a policy implication, our findings don't support the view that firms can absorb or mitigate negative effects of large exchange rate volatility on their exports by higher productivity or price powers through the sophisticated supply-chain networks, particularly for capital equipment or parts and components suppliers. On the other hand, our finding of the sunk cost in the regression model gives a concern on the existence of unit roots in our data because the estimated coefficients are statistically significant and close to unity in most of industries. Future research should consider this problem using longer time series data if possible.

\section{Reference}

[1] Ackerberg, D., Caves, K., Frazer, G., 2006. Structural Identification of Production

[2] Functions. Working Paper, available at http://www.econ.ucla.edu/ackerber/.

\footnotetext{
${ }^{1}$ From the data of the Survey of Oversea Business Activities compiled by the METI, productivity of the firms that export to their own oversea establishments is not always higher than the domestic firms on average.
} 
[3] Ando, M. and Kimura, F. 2013. Trade Adjustments to Exchange Rate Changes by Japanese Manufacturing MNEs: Intra-firms and arm's length transactions. RIETI Discussion Papers, 13-E-023.

[4] Bellone, F., Musso, P., Nest, L., Warzynski, F. 2008. Endogenous Markups,

[5] Firm-Productivity and International Trade: Testing some micro-level implications of the

[6] Melitz-Ottaviano model. Working Paper 08-20, Aarhus School of Business.

[7] Berman, N. Martin, P. and Mayer, T. 2012. How Do Different Exporters React to Exchange Rate Changes? Quarterly Journal of Economics, 127(1), 437-492.

[8] Bond, S., Soderbom, M., 2005. Adjustment Costs and the Identification of

[9] Cobb-Douglas Production Functions. Working Papers W05/04, the Institute for Fiscal

[10] Studies, University Collage London.

[11] Darby, J., Hallett, A. H., Ireland, J. and Piscitelli, L. (1999), 'The impact of exchange

[12] rate uncertainty on the level of investment', The Economic Journal 109, 55\{67.

[13] Eslava, M., Haltiwanger, J., Kugler, A. Kugler, M., 2005. Plant Survival, Market

[14] Fundamentals and Trade Leberalizatino. mimeo.

[15] Guillou. S. 2008. Exports and Exchange Rate: A firm-level investigation. OFCF Working Paper, 2008-2.

[16] Helpman, E., Melitz, M. J., Yeaple, S. R., 2004. Export versus FDI with Heterogeneous

[17] Firms. American Economic Review, 94, 300-316.

[18] Ichimura, H., Konishi, Y., Nishiyama, Y., 2011. An Econometric Analysis of Firm

[19] Specific Productivities: Evidence from Japanese plant level data. Discussion Paper

[20] 11-E-002, Research Institute of Economy, Trade and Industry.

[21] Kato, A., Kodama, N., 2014. Markups, Productivity and External Market Development:

[22] An empirical analysis using small service firms' data. Applied Economics, 46(29), 3601-3608.

[23] Kato, A. 2015a. Effect of Exchange Rate Changes on East Asian Technology-Intensive Exports. The Journal of International Trade and Economic Development. 24(6), 809-821.

[24] Kato, A. 2015b. Does Export Yield Productivity and Markup Premiums? Evidence from the Japanese manufacturing industries. International Review of Research in Emerging Markets and the Global Economy, Vol. 1 (1), 273-285.

[25] Kim, Y-G., Kwon, H-U., Fukao, K., 2007. Entry and Exit of Companies and Establishments, and Productivity at the Industry Level (in Japanese). Discussion Paper

[26] 07-J-022, Research Institute of Economy, Trade and Industry.

[27] Li, H., Ma, H., Xu, Y., and Xiong, Y. 2015. How Do Exchange Rate Movement Affect Chinese Exports?: A firm-level investigation. Journal of International Economics, 97(1), 148-161.

[28] Levinsohn, J., Petrin, A., 2003. Estimating Production Functions Using Inputs to

[29] Control for Unobservables. Review of Economic Studies, 70, 317-342.

[30] Martin R., 2010. Productivity Spreads, Market Power Spreads, and Trade. Discussion

[31] Paper 997, Centre for Economic Performance, London School of Economics and

[32] Political Science.

[33] Melitz, M., 2003. The Impact of Trade on Intra-Industry Reallocations and Aggregate

[34] Industry Productivity. Econometrica 71, 1695-1725.

[35] Morikawa, M. 2015. Uncertainty over Exchange Rates and Exports (in Japanese). RIETI Discussion Papers, 15-J051.

[36] Olley, S., Pakes, A., 1996. The Dynamics of Productivity in the Telecommunication

[37] Equipment Industry. Econometrica, 64, 1263-1297. 
[38] Rahman, M. 2009. The Impact of Real Exchange Rate Flexibility on East Asian Exports. The World Economy.

[39] Shioji, E. 2012. The Evolution of the Exchange Rate Pass-Through in Japan: A re-evaluation based on time-varying parameter VARs. Public Policy Review. 8(1), 67-92.

[40] Tenreyro, S. (2007), 'On the Trade Impact of Nominal Exchange Rate Volatility', Journal of

[41] Development Economics 82, 485-508.

[42] Thorbecke, W. and Kato, A. (2012). The Effect of Exchange Rate Changes on Japanese Consumption Exports. Japan and the World Economy, 24(1), 64-71.

[43] Tokui, J., Inui, T., Kim, YG., 2007. The Embodied Technical Progress and the Average

[44] Vintage of Capital (in Japanese). Discussion Paper 07-J-035, Research Institute of

[45] Economy, Trade and Industry.

[46] Wooldridge, J.M. 2005. Simple solutions to the initial conditions problem in

[47] dynamic, nonlinear panel-data models with unobserved heterogeneity. Journal

[48] of Applied Econometrics, 20(1), 39-54.

\section{Appendix}

\section{Industry Classification}

\begin{tabular}{|l|l|}
\hline Industry Classification & Abbreviation \\
\hline Foods and Beverages & Foods \\
\hline Textile, Clothing and Footwear & Textile \\
\hline Wood and Paper & Woods \\
\hline Chemicals & Chemicals \\
\hline Plastics and Rubber & Plastics \\
\hline Glasses and Ceramics & Glasses \\
\hline Metals & Metals \\
\hline General Purpose Machinery & Machines \\
\hline Electric and Electronic Components & Electronics \\
\hline Transportation Equipment & Transport \\
\hline Miscellaneous & Others \\
\hline
\end{tabular}

Table 1: Regional Share to Export and Export Share to Total Sales

\begin{tabular}{|l|l|l|l|l|l|}
\hline Industry & Asia & US & EU & Others & Export Share to Total Sales \\
\hline Foods & 0.67292 & 0.21038 & 0.08030 & 0.03639 & $0.43 \%$ \\
\hline Textile & 0.74324 & 0.10044 & 0.11675 & 0.03957 & $2.80 \%$ \\
\hline Woods & 0.72767 & 0.13469 & 0.11496 & 0.02268 & $0.91 \%$ \\
\hline Chemicals & 0.68336 & 0.15273 & 0.14270 & 0.02121 & $10.94 \%$ \\
\hline Plastics & 0.75801 & 0.12521 & 0.09324 & 0.02354 & $6.79 \%$ \\
\hline Glasses & 0.73667 & 0.14065 & 0.07840 & 0.04428 & $8.43 \%$ \\
\hline Metals & 0.74472 & 0.14958 & 0.08014 & 0.02556 & $7.27 \%$ \\
\hline Machines & 0.69378 & 0.16249 & 0.11140 & 0.03233 & $27.33 \%$ \\
\hline Electronics & 0.70805 & 0.16231 & 0.10926 & 0.02038 & $23.44 \%$ \\
\hline
\end{tabular}




\begin{tabular}{|l|l|l|l|l|l|} 
Transport & 0.52354 & 0.29314 & 0.12041 & 0.06291 & $30.65 \%$ \\
\hline Others & 0.60288 & 0.18288 & 0.17752 & 0.03671 & $19.48 \%$ \\
\hline
\end{tabular}

Note: Author's own calculation

The averages between 2002 and 2012

Table 2: Distribution of Firms and Ratio of Exporters in Each Size Category

\begin{tabular}{|l|l|l|l|l|l|l|}
\hline & \multicolumn{4}{|l|}{ Firm Size Shares } & \multicolumn{2}{l|}{ \% of Exporters } \\
\hline Industry & $\mathbf{X}>\mathbf{5 0 0}$ & $\mathbf{5 0 0}>\mathbf{X}>\mathbf{1 0 0}$ & $\mathbf{X}<\mathbf{1 0 0}$ & $\mathbf{X}>\mathbf{5 0 0}$ & $\mathbf{5 0 0}>\mathbf{X}>\mathbf{1 0 0}$ & $\mathbf{X}<100$ \\
\hline Foods & $15.71 \%$ & $56.13 \%$ & $28.16 \%$ & $19.39 \%$ & $9.74 \%$ & $5.09 \%$ \\
\hline Textile & $5.60 \%$ & $51.11 \%$ & $43.30 \%$ & $50.30 \%$ & $18.47 \%$ & $12.43 \%$ \\
\hline Woods & $8.70 \%$ & $51.01 \%$ & $40.29 \%$ & $37.77 \%$ & $12.54 \%$ & $6.30 \%$ \\
\hline Chemicals & $19.40 \%$ & $54.12 \%$ & $26.48 \%$ & $77.26 \%$ & $54.10 \%$ & $31.59 \%$ \\
\hline Plastics & $11.11 \%$ & $55.81 \%$ & $33.08 \%$ & $69.03 \%$ & $34.00 \%$ & $18.44 \%$ \\
\hline Glasses & $8.19 \%$ & $52.44 \%$ & $39.37 \%$ & $59.30 \%$ & $28.71 \%$ & $9.68 \%$ \\
\hline Metals & $9.23 \%$ & $52.72 \%$ & $38.05 \%$ & $61.05 \%$ & $29.85 \%$ & $17.28 \%$ \\
\hline Machines & $12.16 \%$ & $53.05 \%$ & $34.79 \%$ & $79.50 \%$ & $56.07 \%$ & $37.97 \%$ \\
\hline Electronics & $20.02 \%$ & $54.83 \%$ & $25.16 \%$ & $62.64 \%$ & $40.14 \%$ & $27.35 \%$ \\
\hline Transport & $23.81 \%$ & $55.15 \%$ & $21.04 \%$ & $66.47 \%$ & $28.55 \%$ & $13.96 \%$ \\
\hline Others & $13.92 \%$ & $54.45 \%$ & $31.63 \%$ & $75.62 \%$ & $51.25 \%$ & $36.87 \%$ \\
\hline
\end{tabular}

Note: Author's own calculation

The averages between 2002 and 2012

Table 3: Average Firm Size, Productivity and Markup

\begin{tabular}{|c|c|c|c|c|c|c|}
\hline \multirow[b]{2}{*}{ Industry } & \multicolumn{2}{|l|}{ Firm Size } & \multicolumn{2}{|l|}{ Productivity } & \multicolumn{2}{|l|}{ Markup } \\
\hline & Non Exporters & Exporters & Non Exporters & Exporters & Non Exporters & Exporters \\
\hline Foods & 342.12 & 694.47 & -0.0103 & 0.3761 & 1.0645 & 1.0099 \\
\hline Textile & 158.46 & 365.00 & 0.1890 & -0.2097 & 0.9575 & 1.1865 \\
\hline Woods & 193.68 & 606.37 & -0.2490 & -0.1295 & 1.0501 & 1.0164 \\
\hline Chemicals & 267.54 & 708.08 & 0.0883 & 0.0071 & 1.0268 & 1.0407 \\
\hline Plastics & 192.18 & 512.23 & 0.1106 & 0.4704 & 1.1221 & 1.0859 \\
\hline Glasses & 166.22 & 458.70 & 0.5512 & 0.4596 & 0.9430 & 1.0082 \\
\hline Metals & 224.28 & 477.92 & 0.0927 & 0.0825 & 1.0831 & 1.0974 \\
\hline Machines & 241.56 & 463.35 & 0.4062 & 0.2720 & 1.1212 & 1.1807 \\
\hline Electronics & 300.66 & 944.47 & -0.0425 & 0.0447 & 0.9449 & 1.0308 \\
\hline Transport & 304.60 & 1586.72 & 0.1397 & 0.6557 & 1.0904 & 1.0408 \\
\hline Others & 206.67 & 411.71 & 0.7305 & 0.8185 & 1.1500 & 1.1634 \\
\hline
\end{tabular}

Note: Author's own calculation

The averages between 2002 and 2011

Table 4: Estimation Results of the Regression Model (Exchange Rates $=$ Yearly Average) 


\begin{tabular}{|c|c|c|c|c|c|c|}
\hline \multirow[b]{3}{*}{ VARIABLES } & \multicolumn{3}{|c|}{$\pi$ is the EXR level } & \multicolumn{3}{|c|}{$\pi$ is the EXR volatility } \\
\hline & (1) & (2) & (3) & (4) & (5) & (6) \\
\hline & Machines & Electronics & Transport & Machines & Electronics & Transport \\
\hline \multirow[t]{2}{*}{$\pi$} & 0.0123 & $-0.0458^{\star * *}$ & $-0.0339^{* * *}$ & $-0.6740^{\star *}$ & $-1.001^{* * *}$ & $-1.3390^{* * *}$ \\
\hline & $(0.776)$ & $(-4.867)$ & $(-6.698)$ & $(-2.445)$ & $(-3.701)$ & $(-8.137)$ \\
\hline \multirow[t]{2}{*}{$\omega$} & -0.0003 & 0.0032 & $0.0171^{* \star *}$ & -0.0003 & 0.0029 & $0.0190^{\star \star *}$ \\
\hline & $(-0.088)$ & $(0.899)$ & $(2.807)$ & $(-0.0905)$ & $(0.810)$ & $(3.129)$ \\
\hline \multirow[t]{2}{*}{$\mu$} & -0.0045 & $0.0137^{\star}$ & $-0.0417^{* *}$ & -0.0044 & $0.0143^{\star \star}$ & $-0.0450^{* *}$ \\
\hline & $(-0.713)$ & $(1.936)$ & $(-2.086)$ & $(-0.703)$ & $(2.010)$ & $(-2.258)$ \\
\hline \multirow[t]{2}{*}{ Firm Size } & $0.0044^{* * *}$ & $0.0028^{* * \star}$ & $0.0045^{\star * *}$ & $0.0043^{* * *}$ & $0.0027^{* *}$ & $0.0046^{* * *}$ \\
\hline & $(3.797)$ & $(2.611)$ & $(3.349)$ & (3.708) & $(2.480)$ & $(3.440)$ \\
\hline \multirow[t]{2}{*}{ Import Share } & -0.4120 & $2.370^{* * *}$ & $5.9910^{\star * *}$ & $2.0250^{\star \star *}$ & $1.5950^{* * *}$ & $7.0460^{* * *}$ \\
\hline & $(-0.347)$ & $(4.800)$ & $(6.463)$ & $(3.160)$ & $(3.647)$ & $(7.603)$ \\
\hline \multirow{2}{*}{$\begin{array}{l}\text { Capital } \\
\text { Intensity }\end{array}$} & -0.0027 & $0.0107^{* *}$ & $0.0177^{\star}$ & -0.0029 & $0.0108^{* *}$ & $0.0178^{\star}$ \\
\hline & $(-0.567)$ & $(2.157)$ & $(1.861)$ & $(-0.614)$ & $(2.186)$ & $(1.881)$ \\
\hline \multirow{2}{*}{$\begin{array}{l}\text { Labour } \\
\text { Intensity }\end{array}$} & $-0.0743^{* * *}$ & $-0.0733^{* * *}$ & -0.0323 & $-0.0734^{* * *}$ & $-0.0769^{* * *}$ & -0.0199 \\
\hline & $(-4.870)$ & $(-4.107)$ & $(-1.284)$ & $(-4.815)$ & $(-4.301)$ & $(-0.793)$ \\
\hline \multirow{2}{*}{$\begin{array}{l}\text { Lag of Dep. } \\
\text { Var. }\end{array}$} & $0.9240^{* * *}$ & $0.9350^{* * *}$ & $0.9320^{\star * *}$ & $0.9240^{\star * *}$ & $0.9360^{* * *}$ & $0.9170^{* * *}$ \\
\hline & (165.3) & $(146.9)$ & (115.4) & (165.3) & $(146.8)$ & $(110.1)$ \\
\hline N. of Obs. & 12,619 & 13,354 & 8,381 & 12,619 & 13,354 & 8,381 \\
\hline
\end{tabular}

Note: z-statistics in the parentheses.

${ }^{* * *},{ }^{* *}$, and ${ }^{*}$ represent the 1,5 , and 10 percent significance levels, respectively.

Table 5: Estimation Results of the Selection Model

\begin{tabular}{|c|c|c|c|}
\hline & (1) & (2) & (3) \\
\hline \multirow{3}{*}{$\begin{array}{l}\text { VARIABLES } \\
\omega\end{array}$} & Machines & Electronics & Transport \\
\hline & $0.119^{* \star *}$ & $0.0746^{*}$ & 0.115 \\
\hline & $(2.718)$ & $(1.826)$ & $(1.475)$ \\
\hline \multirow{2}{*}{$\mu$} & $-0.262^{* \star *}$ & $-0.223^{* *}$ & $-0.338^{*}$ \\
\hline & $(-3.529)$ & $(-2.111)$ & $(-1.918)$ \\
\hline \multirow{2}{*}{ Firm Size } & $0.120^{* \star *}$ & $0.104^{\star \star \star}$ & $0.208^{* \star *}$ \\
\hline & $(5.086)$ & (5.495) & $(8.202)$ \\
\hline & -1.370 & -2.268 & 70.87 \\
\hline & $(-0.732)$ & $(-0.300)$ & $(0.438)$ \\
\hline \multirow[t]{2}{*}{ FDI } & 0.00542 & $0.0646^{* * *}$ & 0.0225 \\
\hline & $(0.450)$ & (3.914) & $(1.434)$ \\
\hline \multirow[t]{2}{*}{ Age } & $8.42 \mathrm{e}-05$ & 0.000258 & -0.000206 \\
\hline & $(0.396)$ & (1.355) & $(-0.655)$ \\
\hline & & & \\
\hline
\end{tabular}




\begin{tabular}{llll} 
Foreign Capital & 0.000849 & $0.00192^{* \star *}$ & 0.000464 \\
Lag of Dep. Var. & $(1.482)$ & $(2.922)$ & $(0.877)$ \\
& $3.075^{* *}$ & $3.221^{* \star *}$ & $3.220^{\star * *}$ \\
& $(83.68)$ & $(84.55)$ & $(62.74)$ \\
Constant & $-1.499^{* * *}$ & $-1.720^{* \star}$ & -4.691 \\
& $(-6.659)$ & $(-2.564)$ & $(-0.921)$ \\
N. of Obs. & 12,619 & 13,354 & 8,381 \\
\hline
\end{tabular}

Note: z-statistics in the parentheses.

${ }^{* * *},{ }^{* *}$, and ${ }^{*}$ represent the 1,5 , and 10 percent significance levels, respectively.

Figure 1

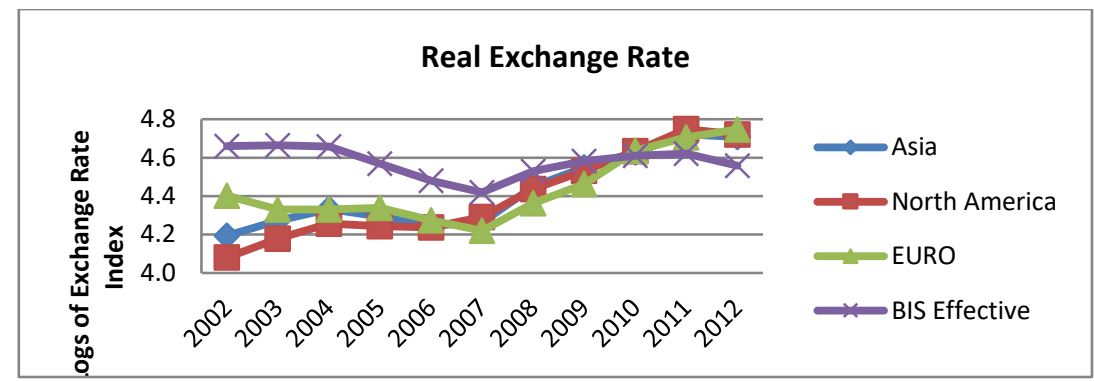

Note: Author's own calculation

Figure 2

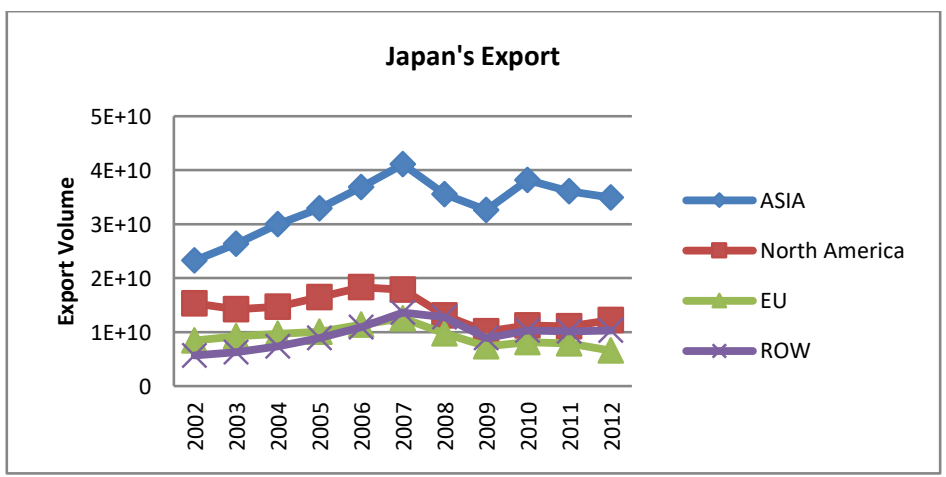

